\title{
Sole transfemoral venous access for cardiac pacemaker implantation
}

\author{
Jana Mareike Nührich, Stephan Willems, Christian Meyer
}

University Heart Center Hamburg, Hamburg, Germany

\section{Correspondence to} Professor Christian Meyer, chr.meyer@uke.de

Accepted 7 June 2016
CrossMark

To cite: Nührich JM, Willems S, Meyer C. BMJ Case Rep Published online: [please include Day Month Year] doi:10.1136/bcr-2016215938

\section{DESCRIPTION}

A 46-year-old man presented to the emergency department, with dizziness and syncopes. ECG revealed a second-degree Mobitz type 2 atrioventricular-block (figure 1A). Owing to a history of thrombosis, phlebography was performed, which showed thrombosis of subclavian veins and the left brachiocephalic vein (figure 1B). Furthermore, the patient suffered from constrictive pericarditis after radiotherapy for a non-Hodgkin's lymphoma. Cardiac MRI showed complete adhesion of almost the entire free and apical right ventricular wall to the pericardium (figure 1C). Since endocardial and epicardial access were missing, an interdisciplinary heart team decided to implant a transcatheter cardiac pacemaker.

The percutaneous implantable transcatheter pacemaker (volume $0.8 \mathrm{cc}$; Micra, Medtronic, Minnesota, USA) was released, via right femoral venous access, in an apical position in the right ventricle (figure 1D). ${ }^{1-3}$ The patient was discharged on the third postoperative day. During 3 months follow-up, the patient experienced no cardiovascular-related adverse events. This case demonstrates that transcatheter pacemaker implantation is a valuable option for patients with sole transfemoral venous cardiac access.

\section{Learning points}

- Leadless pacing is an innovative pacing approach.

- In the setting of sole transfemoral venous cardiac access, transcatheter pacemaker implantation is a valuable option.

\section{Competing interests None declared.}

Patient consent Obtained.

Provenance and peer review Not commissioned; externally peer reviewed.

\section{REFERENCES}

1 Reynolds D, Duray GZ, Omar R, et al. A leadless intracardiac transcatheter pacing system. N Engl J Med 2016;374:533-41.

2 Ritter P, Duray GZ, Steinwender C, et al. Early performance of a miniaturized leadless cardiac pacemaker: the Micra Transcatheter Pacing Study. Eur Heart J 2015;36:2510-9.

3 Meyer C, Jungen C, Gosau N, et al. [Percutaneous implantable transcatheter pacemaker]. Dtsch Med Wochenschr 2016;141:574-7.

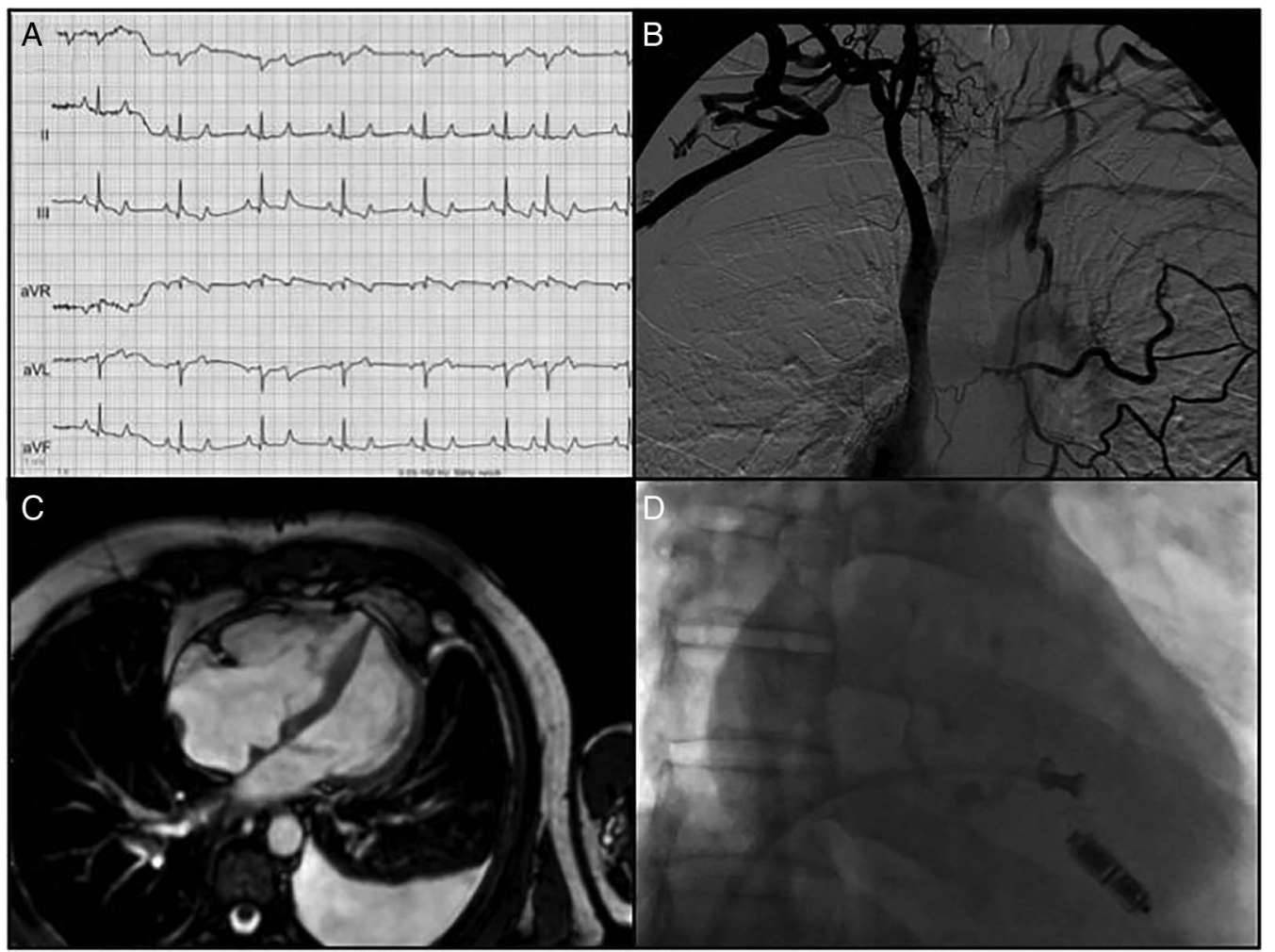

Figure 1 (A) Twelve-lead ECG showing second-degree Mobitz type 2 atrioventricular-block. (B) Multiple thrombosis detected by phlebography. (C) Cardiac MR revealed adhesion of the right ventricle to the pericardium. (D) Fluoroscopy during implantation of the transcatheter pacemaker. 


\section{Images in...}

Copyright 2016 BMJ Publishing Group. All rights reserved. For permission to reuse any of this content visit http://group.bmj.com/group/rights-licensing/permissions.

BMJ Case Report Fellows may re-use this article for personal use and teaching without any further permission.

Become a Fellow of BMJ Case Reports today and you can:

- Submit as many cases as you like

- Enjoy fast sympathetic peer review and rapid publication of accepted articles

- Access all the published articles

- Re-use any of the published material for personal use and teaching without further permission

For information on Institutional Fellowships contact consortiasales@bmjgroup.com

Visit casereports.bmj.com for more articles like this and to become a Fellow 